\title{
Android-based Geographic Information System for Worship Places in Fakfak Regency
}

\author{
Riyadh Arridha $^{1)^{*}}$, Titing Magfirah ${ }^{2)}$, Carlina Dewi Hayunada ${ }^{3)}$, Diah Astuti ${ }^{4)}$ \\ 122)344) Politeknik Negeri Fakfak, Indonesia \\ ${ }^{1)}$ riyadh.arridha@gmail.com, ${ }^{2)}$ titin.magfirah@gmail.com, ${ }^{3)}$ carlinanada@email.com, ${ }^{4)}$ \\ diahastuti0199@gmail.com
}

Submitted : Dec 8, 2021 | Accepted : Jan 10, 2022 | Published : Jan 16, 2022

\begin{abstract}
The rapid development of technology greatly affects people's lives today, one of which in Fakfak City has all been entered by the development of information technology. Fakfak is one of the regencies on the Papua island, the people of Fakfak Regency highly uphold religious values and it is proven by the motto "Satu Tungku Tiga Batu". In Fakfak Regency, one of the the problems faced by some people is the search of worship places that must be done manually, by asking people around, or by looking at a map. In addition, some places of worship have historical values that need to be known by many people. For example, the oldest mosque in Papua and West Papua is in Fakfak Regency. Regarding to this problem, an information system was created that can display information about places of worship in Fakfak. The method used in this research is a waterfall process model. This application is tested using black box methods and questionnaires. The result reveals that an Androidbased application of the Geographic Information System for Places of Worship in Fakfak Regency can help to make it easier for tourists and the Fakfak community to find and obtain information related to places of worship in Fakfak. The results of the black box test state that the functions of the application are running well. The questionnaire test gave results from questions filled out by 20 respondents who stated that the application of the Geographic Information System for Places of Worship was suitable to use by the Fakfak community in obtaining information about places of worship and information on religious history and making it easier for users to find the location of the worship places they wanted to visit.
\end{abstract}

Keywords: GIS, Worship Places, Fakfak, Android

\section{INTRODUCTION}

The rapid development of technology greatly affects people's lives today. One of the impacts of current technological developments is the widespread use of smartphones, various functions in only one device, such as telephone use to internet use, which has penetrated all levels of society from young to old, from cities to remote area (Abdillah, et al., 2020).

Fakfak is one of the districts on the island of Papua. Fakfak Regency is included in the territory of West Papua Province and has an area of 14,320 Km2 (Sinery, 2017). The majority of the population is Muslim, but the people of Fakfak Regency highly uphold religious values and it is proven by the slogan "Satu Tungku Tiga Batu", which has been around for generations (Munasir, 2016). This motto has the meaning of symbols of three religions which are a balanced foundation in supporting the life of the family / clan of the people of Fakfak Regency (Ulumudin, 2015).

Mosques, churches, temples and pagodas are places of worship in Fakfak Regency. The diversity of religious adherents in Fakfak Regency causes the distribution of worship places in Fakfak Regency based on the respective religions. The problem faced by tourists or visitors is the difficulty in finding places of worship. So far, to find the location of worship, visitors usually ask the local community and/or view a map with limited availability and information about worship places. Besides, there are several religious histories and places of worship in Fakfak Regency that visitors should know, for example, the oldest mosque is in Fakfak Regency and could be the oldest in Papua and West Papua (Ernas, 2018).

From the background above, several problems were formulated including how to design, build and implement an Android-based Geographic Information System for Worship Places in Fakfak Regency.

*name of corresponding author 


\section{LITERATURE REVIEW}

According to the research that has been done by Dewi Tresnawati, Leni Fitriani and Agas Moch Fauzan on Design of an Application for Religious Worship Facilities based on Android. They found that utilizing geographic information systems is the right way to provide information about places of worship, because it can be easier to search for worship places and also increases the number of tourists who visiting places of worship in that area (Tresnawati, et al., 2020).

Likewise Made Kresna Negara, Rifky Lana Rahardian, I Gusti Ngurah Dwiky Widiastra who conducted theresarch on Geographic Information System Mapping Places of Worship on the Island of Bali Based on Mobile. It reveals that geographic information system applications are very useful for tourists who will visit an area, because sometimes tourists have difficulty in finding information about the location of worship places. By utilizing the geographic information system, it will be very easy for tourists to find the location of worship as they need (Negara, et al., 2020).

Further, the research conducted by Andri N. Lomboan, Dringhuzen J. Mamahit, Yaulie D.Y. Rindengan entitled Design and Build Applications for Searching Houses of Worship in Kotamobagu Based on Android. In this study, an Android application was developed that mapped the location of worship in the Kotamobagu area (Lomboan, et al., 2018).

However, in the research above, it is not explained whether a web-based back end application was developed to facilitate data management of worship places on the Admin side and also did not provide features of religious history and places of worship in the research area.

\section{METHOD}

In this study, the waterfall method is used to describe the flow of the geographic information system development process. The waterfall model provides a systematic system development approach, starting fromthe systems planning, analysis, design, code, testing and maintenance phases (Aswati, 2017). The waterfall model used is as shown in Fig. 1.

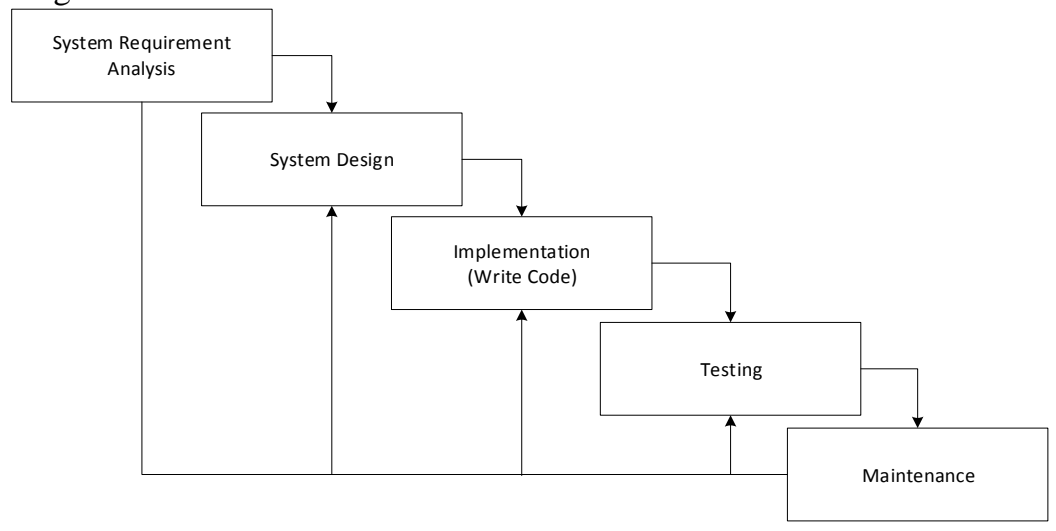

\section{System Requirements Analysis}

Fig. 1 Waterfall Model

This requirements analysis defines the data, process and network requirements that will be implemented in the Android-based Geographic Information System of WorshipPlaces in Fakfak Regency. Based on the results of the requirements analysis, it is known that the built system has 2 user modes, namely Admin and User who are responsible for each user mode as shown in table 1 . Based on table 1 , there will be an admin who is responsible to manage the data of worship places entered into the system through backend application. Meanwhile, the user will access and utilize the application built in the process of finding the location of worship places and also getting information about the history of religion and worship places in the research area.

Table 1 Requirements Analysis

\begin{tabular}{|l|l|l|l|}
\hline No. & Username & \multicolumn{1}{|c|}{ Description } & \multicolumn{1}{|c|}{ Process } \\
\hline 1 & Admin & A person who does the data processing & $\begin{array}{l}\text { Processing data such as names, } \\
\text { addresses, locations and } \\
\text { descriptions of places of worship }\end{array}$ \\
\hline
\end{tabular}

*name of corresponding author 


\begin{tabular}{|l|l|l|lc|}
\hline 2 & User & $\begin{array}{l}\text { A person who will use the information system } \\
\text { to search for worship places data }\end{array}$ & $\begin{array}{l}\text { Looking for locations and } \\
\text { information of worship places } \\
\text { religious history }\end{array}$ \\
\hline
\end{tabular}

\section{System Design}

In making the Geographic Information System for Worship Places in Fakfak Regency, it uses a back end for the admin in the form of a website page using PHP programming language technology and MySQL database. Meanwhile, for the front end, users use the Java programming language in the form of an Android application by utilizing the Google Maps API for mapping and route functions to worship places. In data communication between the back end and the front end, it is used the jsondata exchange which is bridged by the Application Program Interface (API).

The design system defines the process of making Geographic Information System applications for worship places in Fakfak Regency. The design of this application system as depicted in Fig. 2.

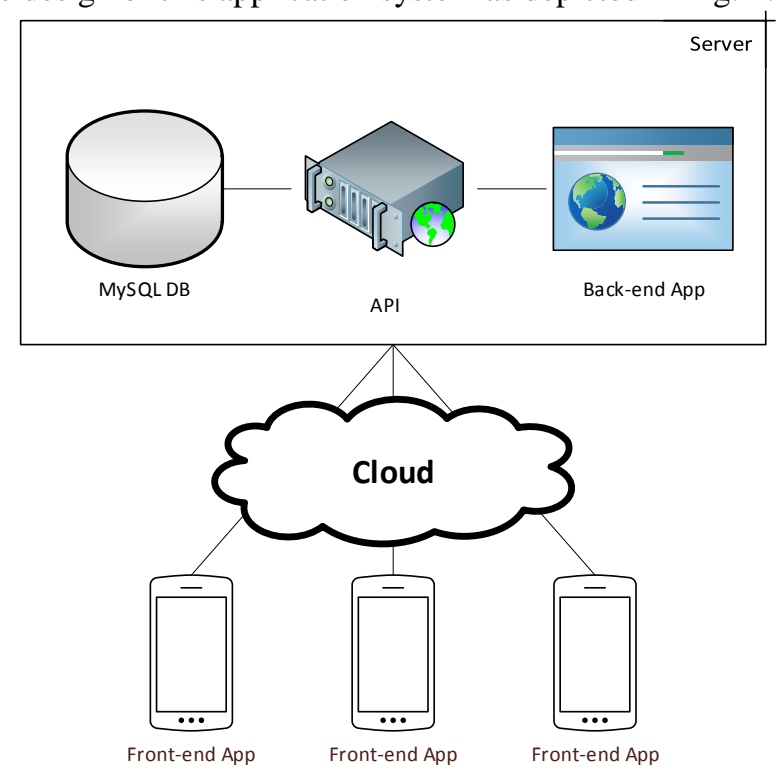

Fig. 2 System Design

Based on the system design in Fig. 2, it can be seen that there is a server that is used as a data storage center for worship places and other data using a MySQL database. Then, there is an API that becomes a bridge in the exchange / transfer of data. Furthermore, a web page is built on the server which becomes back end application. Meanwhile, the server is connected to a smartphone that has the front end application to retrieve and display data on the location of worship places and show the route to the selected location.

In addition, the functional design is a description of the appearance of the Geographic Information System application for worship places in Fakfak Regency. Fig. 3 shows the functional design for the front end display that will be seen by the user. There are three main menu categories in the Android application, namely history, the category of worship places and about. While in the category menu there are five menu options, namely Protestant Churches, Temples, Mosques, Pagoda and Catholic Churches.

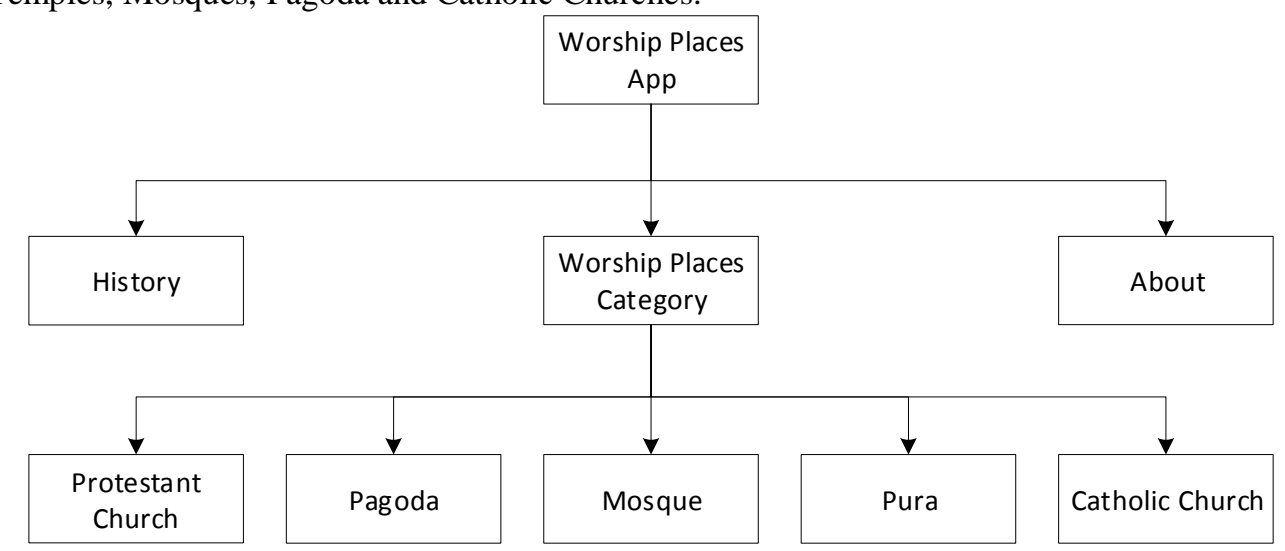

Fig. 3 Functional Design

*name of corresponding author 
For database design, several tables are designed that are used to store data related to system. One of the important tables is the table of worship places. This table contains data related to the location of worship places to be mapped. The table design of worship places is as shown in table 2 .

Table 2 Worship Places

\begin{tabular}{|c|c|c|}
\hline $\begin{array}{c}\text { Nama } \\
\text { Field }\end{array}$ & Type & Panjang \\
\hline Id (PK) & Integer & 15 \\
\hline Nama & Varchar & 100 \\
\hline Alamat & Text & 100 \\
\hline Gambar & Varchar & 50 \\
\hline Longitude & Integer & 20 \\
\hline Latitude & Integer & 20 \\
\hline Keterangan & Varchar & 100 \\
\hline
\end{tabular}

\section{Implementation (Write Code)}

At this stage is the main part that completes the system design. The design must be translated into machinereadable form. In this stage there is code generation. If the design is done completely, coding can be completed mechanically (Prayudi, et al., 2015). At the stage of writing the program code, the back end application is implemented using the PHP programming language. Meanwhile, for the front end application, the Java programming language is used.

\section{Testing}

The testing process focuses on the internal logic of the software to ensure that all statements have been tested. On the external function, it directs the test to find errors and ensure that with limited input, actual results will be obtained as required (Putri, et al., 2021). )

At this stage testing the system used using the Blackbox method. Some of the purpose of testing this system are as follows:

a) Checking the suitability between the system design and the implementation results in the program

b) Ensure that there are no errors (errors) when running the application

c) Ensure the shortest route is drawn correctly (Utami, 2015).

The black box test scenario is used as the first step in testing in which if the black box test does not give the expected results, then the white box method will be used.

\section{Maintenance}

At this stage, the maintenance can be done by checking the system support devices in the form of software and hardware so that they can continue to run normally. As well as providing security to the system (Sutabri, 2012). This stage will be carried out after the application has been running and is used continuously. Yet, in this research the system maintenance process was not carried out because it is only finished at the testing process.

\section{RESULT}

This research produces a web-based back end application and Android-based front end. The back end is used to manage information on the location of worship places by theAdmin while the front end is used to display data location for worship places and history to Android application users. The results of the development of each back end and front end applications are as follows.

\section{Back End}

The backend view begins with the login page. This page is used as an admin login page to perform data maintenance from each place of worship. The data entered for login is in the form of id, username and password as shown in Fig. 4. 


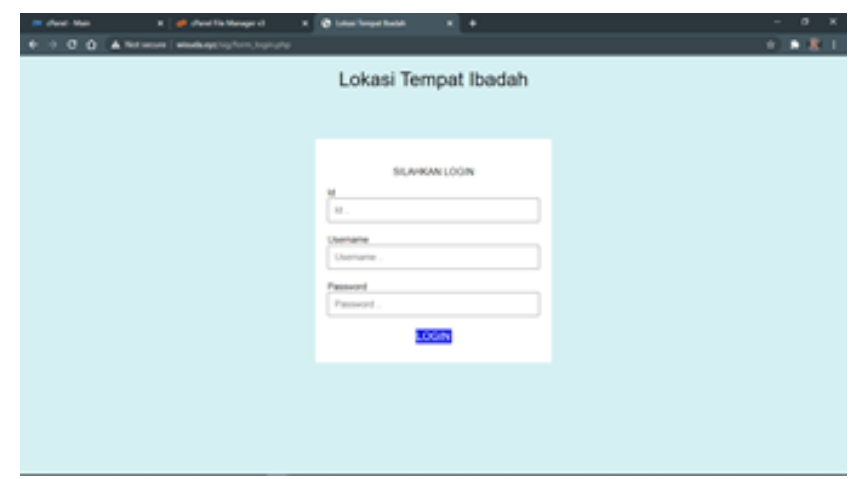

Fig. 4 The Display of Admin Login Page

After logging in, the admin will be taken to the category page for worship place as shown in Fig. 5. This page displays the categories of worship places that can be selected and displays the data of worship places.

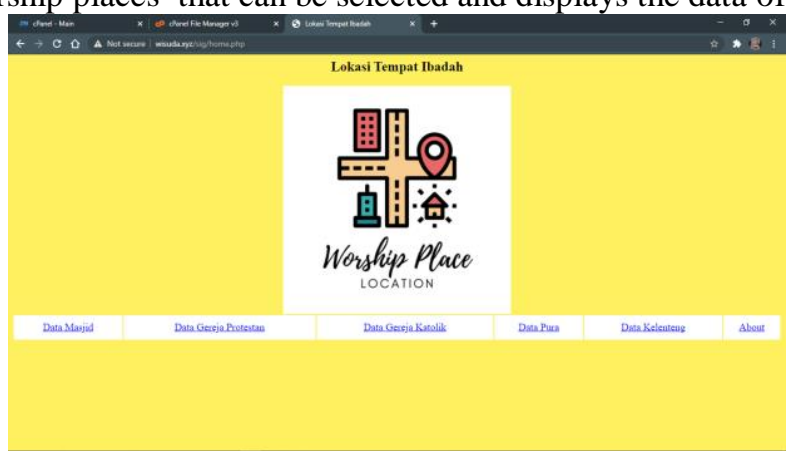

Fig. 5 The Display of Worship Places Category

After selecting a category, we will be taken to the page for data management of worship places based on the category, which can be seen in Fig. 6. On this page, buttons have been prepared to input, update, and delete data.

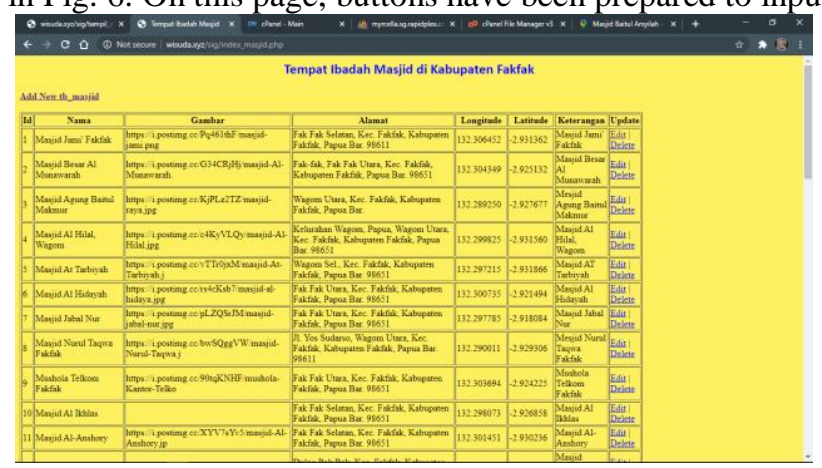

Fig. 6 The Data Page Displays of Worship Places

\section{Front End}

This section shows the implementation of the geographic information system that has been made based on the Android operating system.

The appearance of the first page is splash screen page. This page is the first page that the user sees when the user accesses the Worship Place application, this page is directly connected to the main menu of the application. The splash screen display is shown in Fig. 7. 


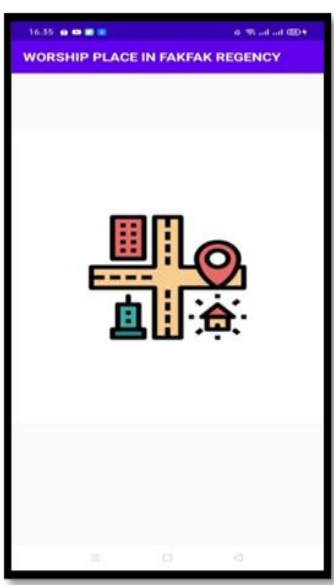

Fig. 7 Splash Screen Application of Worship Places

The next is, the main menu page. This page is the page that will be displayed after the splash screen page. In this main menu there are 3 (three) menu options, namely History, Locations of Worship Places, and About. Users can choose any available menus on this Worship Places Application. The main menu page shown in Fig. 8.

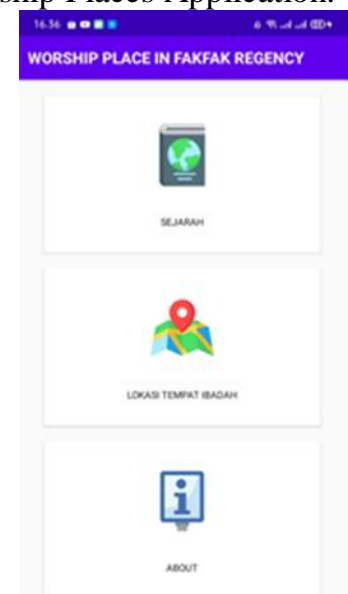

Fig. 8 The Main Menu of Worship Places Application

In the history menu, there are the histories of several religions and also several places of worship in Fakfak Regency as shown in Fig. 9.

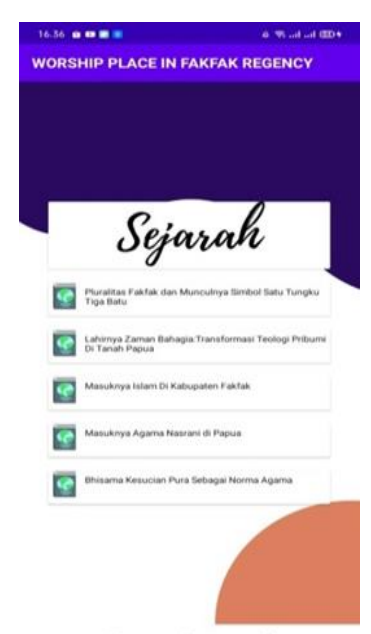

Fig. 9 The History Menu of Worship Places Application 
On the menu Location of Worship Places displays the categories of worship places in Fakfak regency as shown in Fig. 10.

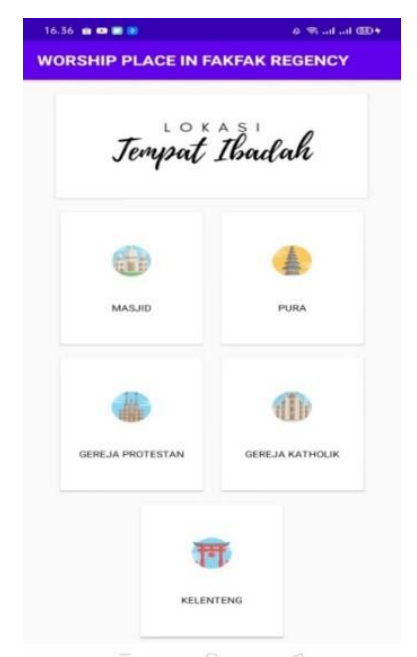

Fig. 10 The Categories of Worship Places

When the user selects a menu from the category, the user's location points and places of worship will also appear according to the selected category as shown in Fig. 11.

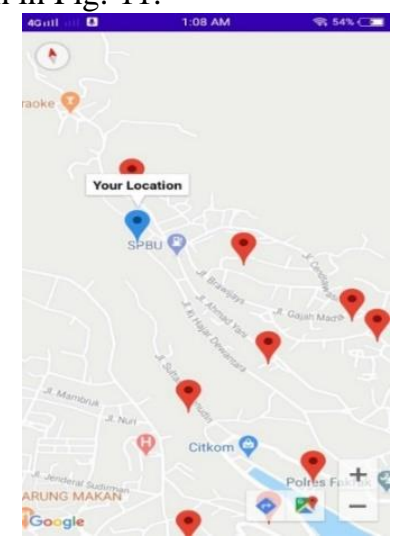

Fig. 11 User Location

Users can select the location of the worship places which will display the name and address of the worship places as shown in Fig. 12. Then, the user can also use the direct feature by pressing the direct location icon which provides information in the form of routes, distances and travel times from the user's location to the place of worship needed.

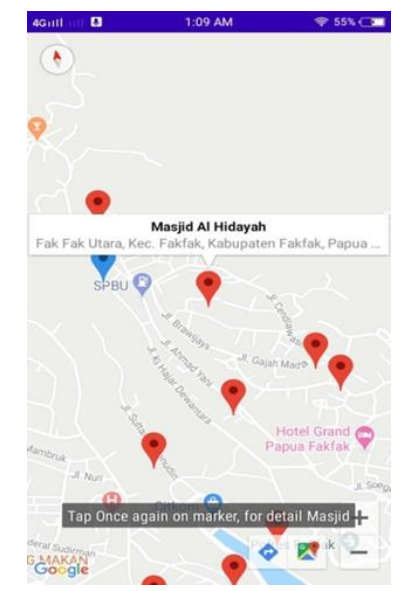

Fig. 12 Locations of Worship Places

*name of corresponding author 
When a place of worship marker is pressed 2 times, it will move to the Details page of the Worship Place and it will display the detailed data of worship place (See Figure 13).

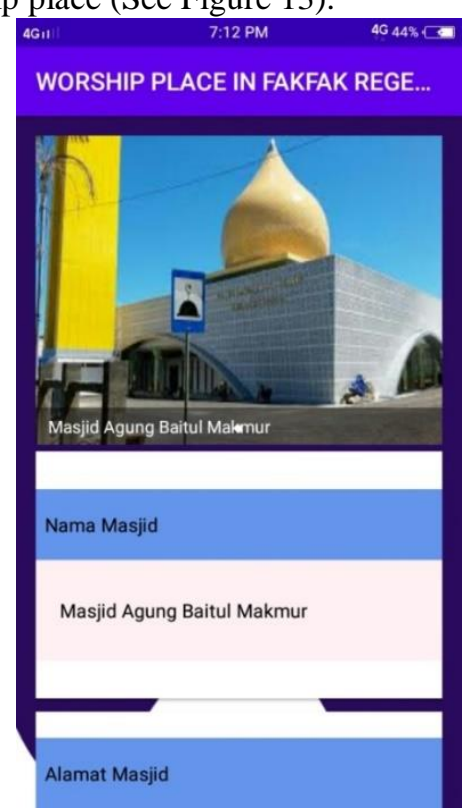

Fig. 13 The Detail Location of Worship Places

Fig. 13 shows the about menu, which is a menu that displays the name and application version created as well as some additional information about the application.

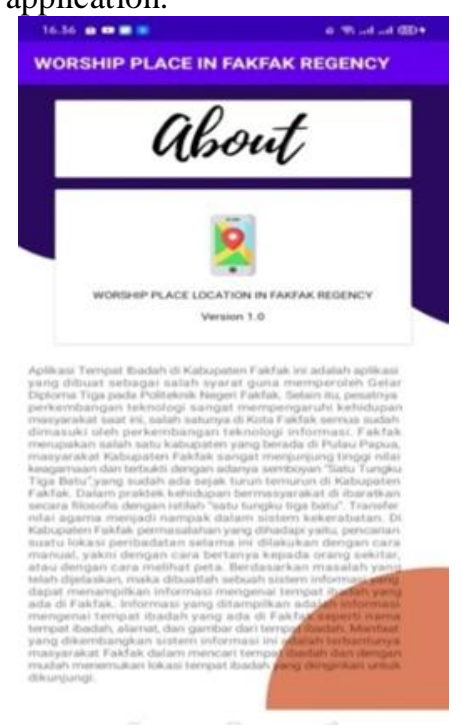

Fig. 13 About Places of Worship Applications

\section{Testing}

The last stage of the making Applications for Worship Places in Fakfak regency is system testing. In this test, the researchers use the Black Box testing method. The functionality of the software tested was in accordance with the use case at the design stage by utilizing the Vivo Y53 smartphone with a Screen Resolution of 540 x 960 pixels, 220 ppi Android system marshmellow 6.0.1 with the following results: 
Table 3 Testing Result

\begin{tabular}{|l|l|l|l|}
\hline \multicolumn{1}{|c|}{$\begin{array}{c}\text { Tested } \\
\text { Components }\end{array}$} & \multicolumn{1}{|c|}{ Process } & \multicolumn{1}{|c|}{ Output } & \multicolumn{1}{|c|}{ Result } \\
\hline App Login Access & Application login & $\begin{array}{l}\text { Successfully logged into the } \\
\text { application }\end{array}$ & Success \\
\hline $\begin{array}{l}\text { The Application } \\
\text { Menu Access }\end{array}$ & $\begin{array}{l}\text { Showing application } \\
\text { menu options }\end{array}$ & $\begin{array}{l}\text { Displays Menu History, Worship } \\
\text { Place Location, and About }\end{array}$ & Success \\
\hline $\begin{array}{l}\text { History Menu } \\
\text { Access }\end{array}$ & $\begin{array}{l}\text { Displaying a historical } \\
\text { list of worship places }\end{array}$ & $\begin{array}{l}\text { Showing the history of Worship } \\
\text { Places and Religion in Fakfak } \\
\text { Regensy }\end{array}$ & Success \\
\hline $\begin{array}{l}\text { Access to } \\
\text { Worship Places }\end{array}$ & $\begin{array}{l}\text { Entrance Process at the } \\
\text { Location } \\
\text { WorshipPlaces Based on } \\
\text { the Category }\end{array}$ & $\begin{array}{l}\text { Displaying categories, locations, } \\
\text { and details of worship Places in } \\
\text { Fakfak Regency }\end{array}$ & Success \\
\hline $\begin{array}{l}\text { The trial of the } \\
\text { route of the the } \\
\text { worship place } \\
\text { location }\end{array}$ & $\begin{array}{l}\text { The process of } \\
\text { displaying the route to } \\
\text { the location of the } \\
\text { worship place }\end{array}$ & $\begin{array}{l}\text { Displaying the route to the location } \\
\text { of worship place based on the } \\
\text { chosen place of worship or to the } \\
\text { location of the nearest place of } \\
\text { worship from the user's location }\end{array}$ & Success \\
\hline $\begin{array}{l}\text { Access to the } \\
\text { About } \\
\text { Application Menu }\end{array}$ & $\begin{array}{l}\text { Login Process on About } \\
\text { Displaying information of } \\
\text { application name and version. }\end{array}$ & Success \\
\hline
\end{tabular}

Besides to functional testing using the black box method, user testing is also carried out. The test was carried out to find out the user's response or reaction to the application for finding the location of worship places in Fakfak Regency. The questionnaire that was distributed by the researcher to 20 respondents consisted of 2 groups, namely, 10 people from outside the city of Fakfak and 10 from the native of Fakfak. The components tested are based on the questionnaire items below as shown in table 4.

Table 4 Questionnaire Items

\begin{tabular}{|c|c|}
\hline No & Questionnaire Items \\
\hline 1. & Shape conformity \\
\hline 2. & Buttons Placement \\
\hline 3. & Match the function of the buttons with the displayed menu \\
\hline 4. & Ease of the operating the application \\
\hline 5. & The information provided is understable \\
\hline 6. & Text color matches of the background \\
\hline 7. & Text size match \\
\hline 8. & Application display suitability \\
\hline 9. & Useful app \\
\hline 10. & Buttons work perfectly \\
\hline
\end{tabular}

Table 5 shows the results of the recapitulation of the questionnaires by respondents containing 5 assessment categories, namely Strongly Agree (SS), Agree (S), Neutral (N), Disagree (TS), and Strongly Disagree (STS).

Table 5 Questionnaire Results

\begin{tabular}{|c|c|c|c|c|c|c|c|}
\hline \multirow{2}{*}{$\begin{array}{l}\text { Ques } \\
\text { tion }\end{array}$} & \multicolumn{5}{|c|}{ Respondent } & \multirow{2}{*}{ Total score } & \multirow{2}{*}{ Percentage } \\
\hline & SS & $\mathbf{S}$ & $\mathbf{N}$ & TS & STS & & \\
\hline $\mathrm{P} 1$ & 5 & 10 & 2 & 3 & 0 & 77 & $77 \%$ \\
\hline $\mathrm{P} 2$ & 7 & 7 & 4 & 2 & 0 & 79 & $79 \%$ \\
\hline P3 & 6 & 10 & 2 & 2 & 0 & 80 & $80 \%$ \\
\hline
\end{tabular}

*name of corresponding author 


\begin{tabular}{|c|c|c|c|c|c|c|c|}
\hline P4 & 7 & 10 & 3 & 0 & 0 & 84 & $84 \%$ \\
\hline P5 & 10 & 10 & 0 & 0 & 0 & 90 & $90 \%$ \\
\hline P6 & 6 & 14 & 0 & 0 & 0 & 86 & $86 \%$ \\
\hline P7 & 4 & 12 & 2 & 2 & 0 & 78 & $78 \%$ \\
\hline P8 & 6 & 12 & 2 & 0 & 0 & 84 & $84 \%$ \\
\hline P9 & 7 & 13 & 0 & 0 & 0 & 87 & $87 \%$ \\
\hline P10 & 6 & 10 & 2 & 2 & 0 & 80 & $80 \%$ \\
\hline
\end{tabular}

Table 5 shows the results of the questionnaire with a total of 20 respondents and 10 questions. In each of the questions submitted, each has 5 assessments, namely SS assuming a value of $5, \mathrm{~S}$ assuming a value of $4, \mathrm{~N}$ assuming a value of 3 , TS assuming a value of 2, and STS assuming a value of 1 . The maximum score is 100 for each component. question. The assumption of this value is used to determine the percentage of the calculation results with the formula (1).

$$
P \frac{\text { Lanswer score }}{\text { Vrespondent } x \text { max score }} \times 100 \%
$$

\section{DISCUSSIONS}

Based on the results of black box testing on the Geographic Information System application for worship places in Fakfak Regency, which displays application access, menu access, history access, access to worship places, testing routes for worship places, access about applications running properly or successfully.

According to the results of user testing about the advantages of the Geographic Information System application for Worship Places in Fakfak Regency. It is ofiund that the application are easy to operate by the community with the highest percentage of P5 in the amount of $90 \%$ and the lowest percentage is P1 and P7 in $77 \%$ and $78 \%$, respectively. However, this application has advantages and disadvantages, the advantages of this application are ; displaying maps of the location of worship places and providing historical information from several religions. Menwhile the drawback of this application is, Sit can only be accessed online in order to be able to display maps of worship places.

Some parts that can be developed from this application is the addition of features for offline map access specifically for the Fakfak Regency. It can also be added a reminder feature for daily worship activities according to the choice of religious category. In addition, the addition of a religious calendar feature that contains important religious activities during the current calendar year can also improve the functionality of this application.

\section{REFERENCES}

Abdillah, L. A., Alwi, M. H., Simarmata, J., Bisyri, M., Nasrullah, N., Asmeati, A., ... \& Bachtiar, E. (2020). Aplikasi Teknologi Informasi: Konsep dan Penerapan. Yayasan Kita Menulis.

Aswati, S., Ramadhan, M. S., Firmansyah, A. U., \& Anwar, K. (2017). Studi Analisis Model Rapid Application Development Dalam Pengembangan Sistem Informasi. MATRIK: Jurnal Manajemen, Teknik Informatika dan Rekayasa Komputer, 20-27.

Ernas, S. (2018). Politik Simbol dan Harmoni Sosial: Makna Satu Tungku Tiga Batu dalam Dinamika Politik Lokal di Fakfak Papua Barat. Dialektika, 9(2).

Lomboan, A. N., Mamahit, D. J., \& Rindengan, Y. D. (2018). Rancang Bangun Aplikasi Pencarian Rumah Ibadah Di Kotamobagu Berbasis Android. Jurnal Teknik Informatika, 13(2).

Munasir, M. (2016). Strategi dakwah AFKN (Al-Fatih Kaaffah Nusantara) dalam pemberdayaan masyarakat Islam Kabupaten Fakfak Papua Barat (Doctoral dissertation, UIN Walisongo).

Negara, M. K., Rahardian, R. L., \& Widiastra, I. G. N. D. (2020). Sistem Informasi Geografis Pemetaan Tempat Ibadah Pada Pulau Bali Berbasis Mobile. Journal of Innovation Information Technology and Application (JINITA), 2(1), 56-66.

Prayudi, K. A. W., Arthana, I. K. R., \& Wirawan, I. M. A. (2015). Pengembangan Game Labrin Matematika Tingkat SD. KARMAPATI (Kumpulan Artikel Mahasiswa Pendidikan Teknik Informatika), 4(5), 414-421.

Putri, A. R., Hafizhah, A., Rahmah, F. H., Muslikhah, R., \& Nabila, S. (2021). PERANCANGAN SISTEM INFORMASI PENJUALAN OBAT ONLINE PADA APOTEK DARA BERBASIS WEBSITE. Jurnal Akrab Juara, 6(4), 100-107.

*name of corresponding author 
Sinery, A. S. (2017). Kajian Lingkungan Hidup Strategis: RPJMD Kabupaten Fakfak 2016-2021. Deepublish. Sutabri, T. (2012). Analisis sistem informasi. Penerbit Andi.

Tresnawati, D., Fitriani, L., \& Fauzan, A. M. (2020). Rancang Bangun Aplikasi Fasilitas Ibadah Keagamaan Berbasis Android. Jurnal Algoritma, 17(1), 60-67.

Ulumudin, Z. (2015). Peran tokoh agama bagi perkembangan komunitas muslim di Fakfak Papua Barat (Doctoral dissertation, UIN Walisongo).

Utami, F. H. (2015). Rekayasa Perangkat Lunak. Deepublish. 